Original Research Paper

\title{
TINGKAT STRES TERHADAP MOTIVASI BELAJAR DI MASA PANDEMI CORONA VIRUS DISEASE 19 (COVID 19) PADA MAHASISWA KEPERAWATAN STIK SITI KHADIJAH PALEMBANG
}

\author{
${ }^{1}$ Lenny Astuti, ${ }^{2}$ Lily Marleni*, ${ }^{3}$ Lela Aini \\ ${ }^{1,3}$ Program Studi Ilmu Keperawatan, Sekolah Tinggi Ilmu Kesehatan Siti Khadijah Palembang \\ ${ }^{2}$ Program Studi D-III Keperawatan, Sekolah Tinggi Ilmu Kesehatan Siti Khadijah Palembang \\ Jalan Demang Lebar Daun Lorok Pakjo, 30137
}

\section{Email Corresponding: \\ lilyasheeqa@gmail.com}

Page : $68-74$

\section{Kata Kunci :}

Stress,

Motivasi Belajar,

Covid 19

Keywords:

Stress,

Learning Motivation,

Covid 19

\begin{abstract}
Tujuan penelitian ini adalah untuk mengetahui apakah ada hubungan Motivasi Belajar Mahasiswa Program Studi D-III Keperawatan Sekolah Tinggi Ilmu Kesehatan Siti Khadijah Palembang Tahun 2020. Rancangan penelitian yang digunakan adalah deskriptif analitik dengan pendekatan cross sectional. Desain tersebut dipilih karena penelitian, pengukuran atau pengamatan dilakukan secara bersamaan (sekali waktu) dan untuk melihat hubungan antara variabel independen dan variabel dependen. Jumlah sampel dalam penelitian ini yaitu sebanyak 113 responden. responden yang mengalami stress berat sebanyak 57 responden $(50,4 \%)$ lebih banyak dibandingkan dengan responden yang mengalami stress ringan sebanyak 56 responden $(49,6 \%)$. responden yang memiliki motivasi kuat sebanyak 99 respoden $(87,6 \%)$ lebih banyak di bandingkan dengan responden yang memiliki motivasi sedang sebanyak 12 responden $(10,6 \%)$ dan motivasi lemah sebanyak 2 responden $(1,8 \%)$. Tidak Ada hubungan bermakna antara tingkat stress dan motivasi belajar dengan nilai $\mathrm{p}$ value 0,846 .
\end{abstract}

ABSTRAK

\section{ABSTRACT}

The purpose of this study was to determine whether there was a relationship between the Student Motivation of the D-III Nursing Study Program of the Siti Khadijah Palembang High School of Health in 2020. The research design used was descriptive analytic with a cross sectional approach. The design was chosen because research, measurements or observations were carried out simultaneously (once at a time) and to see the relationship between the independent variable and the dependent variable. The number of samples in this study were 113 respondents. Respondents who experienced severe stress were 57 respondents (50.4\%) more than respondents who experienced mild stress as many as 56 respondents (49.6\%). 99 respondents (87.6\%) had strong motivation more than 12 respondents (10.6\%) who had moderate motivation and 2 respondents (1.8\%) had weak motivation. There is no significant relationship between stress levels and learning motivation with a $p$ value of 0.846
Published by:

Tadulako University,

Managed by Faculty of Medicine.

Email: healthytadulako@gmail.com

Phone (WA): +6285242303103

Address:

Jalan Soekarno Hatta Km. 9. City of

Palu, Central Sulawesi, Indonesia

\section{PENDAHULUAN}

Seorang individu akan memiliki respon terhadap kejadian yang memicu adanya stress (stressor) ${ }^{1}$. Stres adalah kondisi yang disebabkan oleh interaksi antara individu dengan ligkungan, menimbulkan persepsi tuntutan-tuntutan yang berasal dari situasi yang bersumber pada sistem biologis, psikologis dan sosial dari seseorang ${ }^{2}$. Stres juga bisa diartikan sebagai tekanan, ketegangan atau gangguan yang tidak menyenangkan yang berasal dari luar diri seseorang ${ }^{3}$. Penggolongan stress terdiri dari dua jenis, yaitu stress yang membangun atau dikenal dengan istilah eustress. Eustress membuat seseorang bersemangat dan meningkatkan konsentrasi belajar, sedangkan stress yang sifatnya tidak menyenangkan dan 
bersifat negative dikenal dengan distress. Distress memberikan berbagai dampak negative seperti menjadi gugup, tekanan darah tinggi, mudah marah, sulit berkonstrasi dan tidak memiliki. Salah satu contoh stress negative (distress) yaitu stress akademik.

Stress akademik adalah stress yang terjadi di lingkugan pendidikan. Stress akademik muncul ketika terlalu banyak tuntutan dan tugas yang harus diselesaikan seorang mahasiswa ${ }^{4}$. Ditambah lagi di masa era pandemic seperti ini, yang mengharuskan mahasiswa belajar melalui dalam jaringan (daring). Khususnya pada mahasiswa STIK Siti Khadijah Palembang yang selama masa pandemic covid 19 ini diharuskan melaksanakan proses belajar mengajar secara online melalui e- class, e- learning, maupun berbagai media lainnya yang berbasis online. Hal tersebut dapat mengakibatkan mahasiswa merasa terbebani.

Pendidikan perguruan tinggi merupakan suatu sistem yang menuntut pembelajaran yang mandiri dan disipilin, kemudian dalam setiap kegiatan pembelajaran selalu didasari oleh keinginan dari individu itu sendiri. Keinginan tersebut dapat berupa motivasi untuk belajar. Motivasi akan mendorong seorang mahasiswa untuk mencapai hasil belajar. Motivasi seseorang akan menentukan tingkat pencapaian prestasi atas usaha yang dilakukan 5 .

Pencapaian hasil belajar mahasiswa tidak hanya dipengaruhi oleh stress saja, namun terdapat hal lain yang ikut mempengaruhi yaitu motivasi belajar. Motivasi belajar dipengaruhi oleh dua aspek yaitu aspek intrinsik dan aspek ekstrinsik. Aspek intrinsik menggambarkan motivasi internal seseorang untuk melakukan sesuatu untuk mencapai tujuannya, misal seorang mahasiswa akan belajar karena senang dengan pelajaran tersebut. Aspek ekstrinsik menggambarkan motivasi seseorang untuk mendapatkan sesuatu karena dipengaruhi adanya imbalan atau hukuman, misal seorang mahasiswa akan belajar karena dia harus mendapatkan nilai yang baik ${ }^{6}$.

Menurut Sakamoto peningkatan stres pada mahasiswa akan menurunkan tingkat motivasi seseorang ${ }^{7}$. Hal ini juga sejalan dengan penelitian Puspita yang mengatakan adanya hubungan bermakna antara stress terhadap motivasi belajar. Hasil ini juga diperkuat oleh penelitian Rucker, Park et al dan Strucher didapatkan hasil yang sama bahwa terdapat hubungan yang signifikan antara tingkat stress dengan motivasi belajar.

Berdasarkan uraian di atas, maka peneliti tertarik untuk meneliti mengenai Tingkat Stress terhadap Motivasi Belajar Mahasiswa Program Studi D-III Keperawatan Sekolah Tinggi Ilmu Kesehatan Siti Khadijah Palembang Tahun 2020

\section{Metode Penelitian}

Rancangan penelitian yang digunakan adalah deskriptif analitik dengan pendekatan cross sectional. Desain tersebut dipilih karena penelitian, pengukuran atau pengamatan dilakukan secara bersamaan (sekali waktu) dan untuk melihat hubungan antara variabel independen dan variabel ${ }^{8}$. dalam penelitian ini adalah semua mahasiswa Program Studi D-III Keperawatan STIK Siti Khadijah Palembang yang berstatus aktif, dan sampel yang bersedia pada penelitian yaitu sebanyak 113 responden yang terdiri dari mahasiswa D-III Keperawatan semester I, III, dan V. Teknik pengumpulan data dilakukan peneliti dengan cara memberikan kuesioner kepada responden. Adapun data yang akan diambil adalah Data Primer dan data sekunder. Analisis yang dilakukan terhadap dua variabel yang diduga berhubungan atau berkorelasi, yaitu kriteria tingkat stress dan motivasi belajar dengan menggunakan Uji Chi Square dengan software SPSS 17 , dimana $\mathrm{p} \leq$ apha 0,05 maka ada Hubungan Tingkat Stress dengan Motivasi Belajar pada Mahasiswa STIK Siti Khadijah 
Palembang Tahun 2020. Sedangkan $\mathrm{p}>0,05$ tidak ada Hubungan Tingkat Stress dengan Motivasi Belajar pada Mahasiswa STIK Siti Khadijah Palembang Tahun 2020.

\section{HASIL}

\section{Analisa Univariat}

\section{Tingkat Stress}

Hasil penelitian menunjukkan distribusi frekuensi responden menurut tingkat stress setelah dikategorikan terlihat dalam tabel berikut :

Tabel 1. Distribusi Frekuensi Tingkat Stress pada Mahasiswa Keperawatan di STIK Siti Khadijah Palembang Tahun 2020

\begin{tabular}{llcc}
\hline No & Tingkat Stress & Jumlah & $\begin{array}{c}\text { Persentase } \\
(\boldsymbol{\%})\end{array}$ \\
\hline 1 & Stress Berat & 57 & 50,4 \\
\hline 2 & Stress Ringan & 56 & 49,6 \\
\hline & Jumlah & 113 & 100
\end{tabular}

Berdasarkan tabel.1 diatas didapatkan bahwa responden yang mengalami stress berat sebanyak 57 responden $(50,4 \%)$ lebih banyak dibandingkan dengan responden yang mengalami stress ringan sebanyak 56 responden $(49,6 \%)$.

\section{Motivasi Belajar}

Hasil penelitian menunjukkan distribusi frekuensi responden menurut motivasi belajar setelah dikategorikan terlihat dalam tabel berikut :

Tabel .2

Distribusi Frekuensi Motivasi Belajar pada Mahasiswa Keperawatan di STIK Siti Khadijah Palembang Tahun 2020

\begin{tabular}{llcc}
\hline No & \multicolumn{1}{c}{$\begin{array}{c}\text { Motivasi } \\
\text { Belajar }\end{array}$} & Jumlah & $\begin{array}{c}\text { Persentase } \\
(\boldsymbol{\%})\end{array}$ \\
1 & Motivasi Kuat & 99 & 87,6 \\
2 & Motivasi & 12 & 10,6 \\
& Sedang & & \\
3 & Motivasi Lemah & 2 & 1,8 \\
& Jumlah & 113 & 100 \\
\hline
\end{tabular}

Berdasarkan tabel.2 diatas didapatkan bahwa responden yang memilili motivasi kuat sebanyak 99 respoden $(87,6 \%)$ lebih banyak di bandingkan dengan responden yang memiliki motivasi sedang sebanyak 12 responden $(10,6 \%)$ dan motivasi lemah sebanyak 2 responden $(1,8 \%)$.

\section{Analisa Bivariat}

Analisa bivariat dilakukan dengan uji ChiSquare untuk menemukan bentuk hubungan statistik antara tingkat stress dan motivasi belajar dengan nilai kemaknaan $\alpha=0,05$. Jika $p$ value $\leq 0,05$, maka ada hubungan bermakna antara tingkat stress dan motivasi belajar. Sebaliknya, jika pvalue >0,05, maka tidak ada hubungan bermakna antara tingkat stress dan motivasi belajar.

\section{Hubungan antara Tingkat Stress dan Motivasi Belajar}

\section{Tabel.3}

Hubungan Tingkat Stress dengan Motivasi Belajar pada Mahasiswa Keperawatan STIK Siti Khadijah Palembang Tahun 2020

\begin{tabular}{|c|c|c|c|c|c|c|c|c|c|c|}
\hline \multirow[t]{3}{*}{ No } & \multirow{3}{*}{$\begin{array}{l}\text { Tingkat } \\
\text { Stress }\end{array}$} & \multicolumn{6}{|c|}{ Motivasi Belajar } & \multicolumn{2}{|c|}{ Jumlah } & \multirow[t]{3}{*}{ pvalue } \\
\hline & & \multicolumn{2}{|c|}{ Kuat } & \multicolumn{2}{|c|}{ Sedang } & \multicolumn{2}{|c|}{ Lemah } & & \multirow[b]{2}{*}{$\%$} & \\
\hline & & $\mathrm{n}$ & $\%$ & $\mathrm{~N}$ & $\%$ & $\mathrm{n}$ & $\%$ & $\mathrm{n}$ & & \\
\hline 1 & Berat & 49 & 43,4 & 7 & 6,19 & 1 & 0,88 & 57 & 50,4 & \multirow[t]{3}{*}{0.846} \\
\hline 2 & Ringan & 50 & 44,2 & 5 & 4,42 & 1 & 0,88 & 56 & 49,6 & \\
\hline & Jumlah & & & & & & & 113 & 100 & \\
\hline
\end{tabular}


Berdasarkan tabel 3 diatas didapatkan hasil hubungan dari tingkat stress dan motivasi belajar menunjukkan bahwa dari 57 responden yang memiliki stress berat dengan motivasi kuat sebanyak 49 responden $(43,4 \%)$ lebih sedikit jika dibandingkan dengan responden yang memiliki stress berat dengan motivasi yang kuat sebanyak 50 responden $(44,2 \%)$.

Berdasarkan hasil uji statistik yang menggunakan Uji Chi-Square melihat signifikansi hubungan didapatkan nilai $p$ value $0,846>\alpha(0,05)$ yang artinya tidak ada hubungan yang bermakna antara tingkat stress dan motivasi belajar pada mahasiswa keperawatan STIK Siti Khadijah Palembang Tahun 2020.

\section{PEMBAHASAN}

\section{Analisa Univariat}

\section{Tingkat Stress}

Berdasarkan hasil penelitian yang mengalami stress berat sebanyak 57 responden $(50,4 \%)$ lebih banyak dibandingkan dengan responden yang mengalami stress ringan sebanyak 56 responden $(49,6 \%)$.

Keadaan stress yang di alami mahasiswa di dunia perkuliahan sering disebut dengan stress akademik. Stress akademik adalah stress yang terjadi di lingkungan pendidikan, stress ini muncul ketika terlalu banyak tuntutan dan tugas yang harus dikerjakan oleh mahasiswa ${ }^{4}$.

Stress juga dapat muncul karena tekanan untuk menunjukkan prestasi dan keunggulan akademik yang semakin meningkat. Hal ini dapat mengakibatkan mahasiswa akan merasa terbebani $^{9}$

Hal ini sejalan dengan penelitian yang dilakukan oleh Puspita yaitu tentang hubungan stress dengan motivasi belajara pada mahasiswa kedokteran dengan hasil penelitian menunjukkan bahwa dimensi stress akibat permasalahan akademik merupakan dimensi tertinggi yang menyebabkan mahasiswa mengalami stress berat ${ }^{10}$.

Berdasarkan hasil penelitian, teori, dan penelitian terkait maka peneliti berasumsi bahwa stress terjadi apabila adanya ketidakseimbangan antara tuntutan dan kemampuan yang artinya stress yang dialami oleh mahasiswa berkaitan dengan sumber atau penyebab stressnya.

\section{Motivasi Belajar}

Berdasarkan hasil penelitian didapatkan bahwa responden yang memilili motivasi kuat sebanyak 99 respoden $(87,6 \%)$ lebih banyak di bandingkan dengan responden yang memiliki motivasi sedang sebanyak 12 responden (10,6 $\%$ ) dan motivasi lemah sebanyak 2 responden $(1,8 \%)$.

Menurt Clayton Aldefer dalam Hamdhu motivasi belajar adalah kecenderungan mahasiswa dalam melakukan segala kegiatan belajar yang didorong oleh hasrat untuk mencapai prestasi hasil belajar sebaik mungkin ${ }^{11}$.

Motivasi belajar adalah penggerak atau pendorong untuk melakukan kegiatan belajar serta bersemangat untuk belajar. Motivasi belajar adalah factor psikis yang bersifat nonintelektual yang berperan dalam penumbuhan gairah, merasa senang dan semangat untuk belajar sehingga memiliki banyak energy untuk melakukan kegiatan belajar ${ }^{12}$

Hal ini sejalan dengan penelitian Puspita yang menunjukkan bahwa mahasiswa kedokteran cenderung memiliki motivasi yang tinggi terlihat sebanyak $>60 \%$. Tingkat motivasi yang ditinggi dipengaruhi oleh dua hal baik itu secara instrinsik maupun ekstrinsik. Ditinjau dari segi instrinsik hal yang mempengaruhi mahasiswa menjadi termotivasi karena adanya rasa ingin tahu yang tinggi dari dalam diri mahasiswa, adanya kemampuan untuk mencapai tujuan dan kemampuan intelektual yang sudah ada dalam diri dapat berupa adanya kebanggaan yang dimiliki oleh mahasiswa ketika mendapatkan nilai yang tinggi sehingga membuatnya terdorong untuk terus mendapatkan nilai yang tinggi diujian selanjutnya ${ }^{6}$ 
Berdasarkan hasil penelitian, teori, dan penelitian terkait maka peneliti berasumsi bahwa mahasiswa yang memiliki motivasi yang kuat dikarenakan adanya dorongan semangat belajar untuk mencapai hasil prestasi yang baik sedangkan mahasiswa yang memiliki motivasi yang sedang dan lemah terjadi ketika mahasiswa tersebut merasa tidak kompeten dan tidak yakin terhadap apa yang dilakukannya.

\section{Analisa Bivariat}

\section{Hubungan antara Tingkat Stress dengan Motivasi Belajar}

Berdasarkan hasil uji statistik yang menggunakan Uji Chi-Square melihat signifikansi hubungan didapatkan nilai $p$ value $0,846>\alpha(0,05)$ yang artinya tidak ada hubungan yang bermakna antara tingkat stress dan motivasi belajar pada mahasiswa keperawatan STIK Siti Khadijah Palembang Tahun 2020.

Menurut Purwanto (2008), factor-faktor yang mempengaruhi motivasi belajar bukan hanya dari factor internal saja seperti factor psikologis atau stress tetapi factor lain yang dapat mempengaruhi motivasi yaitu dari factor eksternal seperti Faktor Sosial (guru, orang tua, konselor) dan Factor non sosial (cuaca, waktu, tempat, sarana dan prasarana(fasilitas belajar)

Fasilitas belajar merupakan faktor ekstrinsik yang mempengaruhi motivasi belajar siswa. Fasilitas belajar meliputi sarana dan prasarana. Fasilitas belajar merupakan salah satu faktor penting untuk membantu proses kegiatan belajar mengajar. Fasilitas belajar sekolah maupun rumah yang baik akan menambah motivasi belajar siswa. Selain fasilitas belajar, faktor lingkungan belajar juga dapat berpengaruh terhadap motivasi belajar siswa. Lingkungan keluarga memiliki peran paling penting dalam menumbuhkan semangat belajar pada anak, karena sebelum mengenal lembaga pendidikan yang lain lingkungan keluarga yang menjadi tempat pertama mereka memperoleh pendidikan dan membentuk kepribadian $^{13}$.

Hal ini sejalan dengan penelitian yang dilakukan oleh Amirudin yang mengatakan bahwa tidak hubungan antara tingkat stress dengan motivasi belajar dengan nilai $p$ value $0,058^{14}$. Deyisi Kalalo dan Mario juga menguatkan tentang hubungan tingkat stress dengan motivasi belajar tidak memiliki hubungan dengan nilai $p$ value 0,062. Hasil tersebut didapatkan bahawa apabila stress rendah maka motivasi belajar tinggi begitupun sebaliknya apabila stress tinggi maka motivasi belajar menurun ${ }^{15}$.

Sama hal nya dengan penelitian Demolingo yang menunjukkan bahwa tidak ada hubungan antara stress dengan motivasi belajar dengan nilai $\mathrm{p}$ value 0,062 . Dari hasil data ditemukan jika stress rendah maka motivasi belajar tinggi dan sebaliknya jika stress tinggi makan motivasi belajar akan menurun dikarenakan stress merupapakan kondisi psikis yang disebabkan oleh berbagai perasaan yang bersifat positif terhadap suatu hal $^{15}$.

Berdasarkan hasil penelitian, teori, dan penelitian terkait maka peneliti berasumsi bahwa stress bukan merupakan indicator utama dalam menentukan motivasi belajar mahasiswa, namun masih banyak indicator lainnya seperti fasilititas belajar, metode pembelajaran yang secara daring di masa pandemic covid 19, lingkungan pendidikan maupun lingkungan keluarga juga dapat mempengaruhi motivasi belajar mahasiswa.

\section{KESIMPULAN DAN SARAN}

\section{Kesimpulan}

1. Distribusi frekuensi responden yang mengalami stress berat sebanyak 57 responden $(50,4 \%)$ lebih banyak dibandingkan dengan responden yang mengalami stress ringan sebanyak 56 responden $(49,6 \%)$. 
2. Distribusi frekuensi responden yang memiliki motivasi kuat sebanyak 99 respoden $(87,6 \%)$ lebih banyak di bandingkan dengan responden yang memiliki motivasi sedang sebanyak 12 responden $(10,6 \%)$ dan motivasi lemah sebanyak 2 responden $(1,8 \%)$.

3. Tidak Ada hubungan bermakna antara tingkat stress dan motivasi belajar dengan nilai $p$ value 0,846 , maka tidak ada hubungan bermakna antara tingkat stress dan motivasi belajar

\section{Saran}

1. Bagi Mahasiswa Keperawatan STIK Siti Khadijah

Diharapkan untuk mahasiswa khususnya mahasiswa keperawatan STIK Siti Khadijah untuk tetap mempertahankan motivasi yang kuat meskipun dalam kondisi pandemic Covid-19 sehingga tetap dapat mendapatkan nilai prestasi yang baik

2. Bagi Institusi Pendidikan

Diharapkan dapat menambah referensi seperti buku, jurnal yang berkaitan dengan stress dan motivasi belajar.

3. Bagi Peneliti Selanjutnya

Diharapkan untuk peneliti selanjutnya dapat menambah variable penelitian yang lain serta metode penelitian yang berbeda dan jumlah sampel yang lebih banyak lagi.

\section{UCAPAN TERIMA KASIH}

Pada kesempatan ini, penulis ingin mengucapkan terima kasih kepada Ketua STIK Siti Khadijah dan Kepala Pusat Penelitian STIK Siti Khadijah yang telah memberikan dukungan dalam penyelesaian penelitian ini.

\section{DAFTAR PUSTAKA}

1. Wahyuni S. Perkembangan Anak Disabilitas. Vol 29. 11th ed. Erlangga; 2018.

2. Sarafino EP. Health Psychology: Biopsychosocial Interactions. Vol 29. 7th ed. New Jersey : John Wiley \&amp; Sons; 2008.

3. American Pshichological. Published online 2013.

4. Ray DC. College Rules! How to Study, Survive, and Succeed in College. Vol 10. Ten Speed Press; 2019. doi:10.24926/jcotr.v10i2.2578

5. Nursalam. Konsep Dan Penerapan Metodologi Penelitian Ilmu Keperawatan. 2nd ed. Salemba Medika; 2008. https://opac.perpusnas.go.id/DetailOpac.a spx?id=317311

6. Rucker TD, Schiff G. Drug Formularies: Myths-in-Formation. Med Care. 1990;28(10):928-942.

7. Sakamoto R. The relationship between motivation, second language learning, and stress in international students. Univ Cent Missouri. Published online 2015.

8. Nursalam. Metodologi Penelitian Ilmu Keperawatan: Pendekatan Praktis. 4th ed. Salemba Medika; 2016.

9. Fernández-González L, GonzálezHernández A, Trianes-Torres MV. Relationships between academic stress, social support, optimism-pessimism and self-esteem in college students. Electron $J$ Res Educ Psychol. 2015;13(1):111-130. doi:10.14204/EJREP.35.14053

10. Puspitha FC, Sari MI, Oktaria D. Hubungan Stres Terhadap Motivasi Belajar Mahasiswa Tingkat Pertama Fakultas Kedokteran Universitas Lampung. J Major. 2018;7(3):24-33.

11. Hamdu G, Agustina L. Pengaruh Motivasi Belajar Siswa Terhadap Pestasi Belajar Ipa Di Sekolah Dasar (Studi Kasus terhadap Siswa Kelas IV SDN Tarumanagara Kecamatan Tawang Kota Tasikmalaya). $J$ Penelit Pendidik. 2011;12(1).

12. Prayascitta P. Hubungan antara coping stress dan dukungan sosial dengan motivasi belajar remaja yang orangtuanya bercerai. Published online 2010.

13. Purwanto. Evaluasi Hasil Belajar. Pustaka Pelajar; 2008.

14. Amirudin I, Rangga E. Stress Dan Motivasi Belajar Mahasiswa Profesi Keperawatan. J Wacana Kesehat. 2019;4(1):420. doi:10.52822/jwk.v4i1.94 
Healthy Tadulako Journal (Jurnal Kesehatan Tadulako) / Vol 7 No.2 Mei 2021

15. Demolingo DPA, Kalalo F, Katuuk ME. Hubungan Stres Dengan Motivasi Belajar Pada Mahasiswa Semester V Program Studi Ilmu Keperawatan Fakultas Kedokteran Universitas Sam Ratulangi Manado. J Keperawatan. 2018;6(1):1. 